\title{
Assessing Democratic Governance in the Nigerian Fourth Republic, 1999 -2014
}

\author{
Salisu Ogbo Usman
}

S. S. Avidime

Department of Political Science, Kogi State University, Anyigba, Kogi State, Nigeria

doi: 10.19044/esj.2016.v12n29p142 URL:http://dx.doi.org/10.19044/esj.2016.v12n29p142

\begin{abstract}
The paper assesses democratic governance in the Nigerian fourth republic. Most Nigerians expected the return to democratic governance on May, 291999 to set the stage for the socio-economic and political transformation of the country. The paper contends that the democratic experience has been problematic for Nigerians. The paper, underpinned by the elite theory, is descriptive, historical and analytical in nature and employs the secondary source in the gathering of data. The paper argues that the uninterrupted character of the democratic transition, improvement in civil and political rights and some economic development dividends are positive outcome of the democratic experience. Yet, the successes associated with the democratic experience seem to have been overshadowed by poor governance, the problems of poverty, de-industrialization, widespread unemployment, large scale collapse of infrastructure, illiteracy, insecurity of lives and property, political corruption, and weak governance institutions. Consequently, public trust in the democratic process, institutions and actors is in decline. The paper suggests amongst others, responsible and effective political leadership and civil society as critical to a productive democratic performance in Nigeria.
\end{abstract}

Keywords: Democratic Governance, Political Corruption, Fourth Republic, State

\section{Introduction}

The democratic governance framework is deeply rooted in the liberal democratic and neoliberal economic agenda (Adejumobi, 2004). According to Omodia and Aliu (2013: 36) the state is expected to practice and promote constitutionalism, respect for the rule of law and human rights, popular participation, accountability and transparency, and probity in the 
management of people and resources. These values largely represent the core essence of democratic governance. Significantly, these key attributes are critical to the capacity of democratic governance to engender and strengthen the social contract, popular trust, state legitimacy and enhance socioeconomic and political development in the society (Omodia and Aliu, 2013).

The return to democratic governance on May 29, 1999 to most Nigerians provided the opportunity to overturn widespread developmental and political problems associated with prolonged military rule and at the same time a hope of great expectations of improved quality of wellbeing and governance. However, many years after democratic rule the huge expectations of most Nigerians have been largely undermined by poor governance, with its attendant socio-economic and political challenges. For example, the Nigerian economy is overwhelmed by the problems of poverty, widening income inequality between the rich and the poor, disinvestment, inflation, deindustrialisation, mass unemployment and debt crisis. Moreover, the crises of widespread collapse of social values, and infrastructure, illiteracy, insecurity of lives and property, political corruption, authoritarianism, electoral malpractices, politically motivated violence, and weak governance institutions continue to undermine the socio-political realm in Nigeria (Seteolu, 2004; Egwemi and Aliu, 2010).

It against this backdrop that the disenchantment and disappointment of most Nigerians with most of the outcomes of the current democratic experience of the fourth republic on their socio-political and economic wellbeing, as evident in the massive decline in popular trust in democratic institutions, processes and political leadership can be appropriately understood and situated (Aliu, 2014). Tragically, this development seems to have overshadowed some of the successes associated with the democratic experience of the fourth republic. The uninterrupted character of the democratic transition and improvement in civil and political freedoms and liberties for example, appeared to have been lost to the popular lamentation over the failure of the democratic experience.

The thrust of the paper is an examination of the extent to which the democratic experience of the fourth republic has impacted on the socioeconomic and political development of Nigeria. The paper is organized into five sections. Section one which is the introduction is followed by section two which discusses the theoretic framework underpinning the study. Meanwhile, section three reviews democratic governance in Nigeria before the fourth republic while section four assesses democratic governance in the Nigerian fourth republic with emphasis on both the gains and pains of the democratic experience. Section five discusses the challenges to democratic governance in the Nigerian fourth republic, while section six which is the 
conclusion contains recommendations on measures towards strengthening democratic governance in Nigeria.

\section{Theoretical Framework}

The elite theory as popularized by Gaetano Mosca (1858-1941), Vilfredo Pareto (1848-1923), and Robert Michels (1876-1936) is adopted for the study. The elite theory succinctly explains the power dynamics and social relations surrounding the acquisition and preservation of state power within the democratic framework. Elites according to Higley (2009: 3) are "persons who, by virtue of their strategic locations in large or otherwise pivotal organizations and movements, are able to affect political outcomes regularly and substantially". Moreover, the elite theory reveals one of the fundamental characters and realities of representative democracy, the balkanization of society into powerful minority, who manipulates and controls the levers of state power and powerless majority governed by the elites.

Although, elites are largely considered as possessing the requisite organizational competence and political knowledge core to steering the political statecraft within the democratic perspective (Omodia, 2011); yet, elitism represents a negation of the key democratic principle of mass ownership of the governance process. Nevertheless, the capacity of the masses to possess the necessary and proper knowledge, values and skills for democratic political leadership is contested. More so, while the classical theory of elitism seems to presume elites as a homogenous group, however the eclectic character of elites as manifested in their diverse social, economic, professional, traditional, bureaucratic and political divisions tend to undermine the cohesive status attached to elites. The diversities invariably underscore the somehow contending and conflicting ideologies, interests, pursuits and orientations and inconsistencies among elites on the one hand and the political elites on the other (Omodia, 2011).

The manipulative and self centered attributes of elites largely underscore the prevailing focus on control of political and state power for protecting and promoting the interests of members at the expense of the masses. In the Nigerian context, the perpetuation of political violence, ethnification of electoral politics, political corruption, hijack of the public policy process and deinstitutionalization of governance institutions are some of the ways elites are known to manipulate the masses so as to sustain their political rule and hegemony (Okoh, 2010; Omodia, 2011). However, these modus oparandi of the Nigerian elites do not only lack sophistication and civility, but contracts fundamentally with elites in developed democracies who accommodates the interests of the masses within the framework of party politics and free and fair elections (Omodia, 2011). 
The elite theory largely explains deeply the role of the Nigerian political leadership and ruling elites in the failure of the state to improve the socio-economic and political conditions of the citizens since the return to democratic governance on May 29, 1999. The issues of godfatherism as well as inter party and intra party violent manifestations in the fourth republic are evidence of elite dangerous contestations for state power (Omodia and Aliu, 2013). Besides, the public character of the public policy making process has been hijacked by the ruling elites to promote their interests. It is curious that while political leaders of the fourth republic have been able to initiate and implement policies that allocate huge sums of money to themselves as allowances and retirement pensions, yet most of these leaders find it difficult to pay pensioners their meager pension and also pay workers the paltry monthly minimum wage of eighteen thousand naira.

\section{Democratic Governance before the Nigerian Fourth Republic}

The character of the State and its politics is core to understanding the performance of the political leadership and democratic governance in Nigeria. Democratic governance in the first republic was largely plagued by political corruption, kleptocracy, and nepotism. Moreover, democratic governance was characterized by 'the sacrifice of governance and nation building on the altar of ethnic, parochial and personal interests' (Omodia and Aliu, 2013: 39). The conspicuous mobilization and manipulation of ethnoreligious sentiments to acquire and consolidate State power and ensure economic control were major attributes of politicians of the first republic (Setolu, 2005). The development partly resulted in the unhealthy rivalry and tensions among Nigerians, and the dangerous conflagrations that enveloped the first republic, as exemplified by the 1962 and 1963 census crisis, 1962 Action Group crisis, and the General Election crisis of 1964 (Omodia and Aliu, 2013; Abdullahi and Saka, 2007).

Democratic governance in the second republic started on October 1, 1979 and marked the termination of the January 15, 1966 military intervention in politics in Nigeria. In general terms, the failure of democratic governance to enhance the delivery of public goods and services and promote societal peace and stability dominated national discourse during the period (Moru, 2005). Specifically, Nigerians have to come to cope with the problems of ineptitude on the part of the political leadership, widespread political corruption; identity based politics, massive electoral malpractices as well as politically motivated violence. Arguably, these factors contributed in part to the collapse of the second republic, with the military overthrow of the civilian government on December 31, 1983 (Omodia and Aliu, 2013; Olaitan, 2005; Ogundiya, 2009). 
The annulment of the June 12, 1993 Presidential elections by the General Ibrahim Badamasi Babangida military regime which would have cemented the transition to democratic process of the regime was a major setback for democratic governance in Nigeria. The singular action contributed in no small measure to the truncation of democratic governance in the third republic. Meanwhile, Omodia and Aliu (2013: 39) contend that subsequent unpopular policies of the National Unity Government (NUG) which replaced the General Ibrahim Badamasi Babangida led military regime and those of the military regimes of Sani Abacha and Abubakar, in the wake of the legitimacy crisis, political upheaval and instability that followed the annulment, partly contributed to:

loss of faith in the state by most citizens, the attendant seeking of alternative platforms especially those rooted in identity politics by some Nigerians to project and promote their interests, the militarisation of the society and emergence of ethnic based groups and militias which endangered national security and stability in the fourth republic.

\section{Assessing democratic governance in the nigerian fourth republic, 1999 -} 2014

\section{Gains of Democratic Governance in the Nigerian Fourth Republic}

With the commencement of democratic governance in 1999, most Nigerians had great expectations that the democratic experience would 'enhance and entrench constitutionalism, respect for human rights, the rule of law, accountability, transparency, popular participation, and improve the economic wellbeing of the people' (Omodia and Aliu, 2013: 39). The high hope expressed by Most Nigerians was borne out of the recognition that in the previous republics, democratic governance was mismanaged by the political leadership and ruling elite with a great blight on the quality of governance, economic development and welfare of the people. Despite the popular perception among most Nigerians that democratic governance in the fourth republic has failed to meet the high level of initial expectations, symbolic and significant socio-economic and political gains and successes associated with the democratic experience of the fourth republic abound.

The democratic governance experience has remained uninterrupted by any form of military adventurism into the foray of politics since it returns on May 29, 1999. Although, the country has witnessed the militarization of civil and electoral processes, a trend that is dangerous for democratic governance during this period. Concomitantly, the country has experienced a civilian to civilian transition for the first time in its democratic history. This indeed represents a symbolic and significant success for the democratic 
experience. Besides, most Nigerians, civil society organizations and the media seem to enjoy greater freedom and liberties with the democratic experience when compared with what was obtainable during military rule.

The functioning of political parties in the forth republic, despite questions about their vibrancy and democratic credentials, largely underscore adherence to political freedom that exist in the democratic governance of the fourth republic. Besides, the legislature, regarded as the bastion of democratic governance, but in most cases the first and major structure of government to be suspended during military rule, exists and continues to function since the return of democratic governance. Although, the legislature of the fourth republic as represented by the National Assembly is perceived by majority of Nigerians to be anti-people and enmeshed in widespread corruption. For example, former Senators Evans Enwerem, Chuba Okadigbo and Adolphos Nwabara were impeached as Senate Presidents for alleged corruption and mismanagement of public fund (Alabi and Fashagba, 2010). Moreover, Honourable Farouk Lawan, as chairman of the House ad hoc committee on the fuel subsidy scam in 2012 allegedly demanded and received $\$ 3 \mathrm{~m}$ bribe from Mr Femi Otedola, a business man whose company was being investigated by the committee (Aliu, 2013).

Moreover, the principle of separation of powers as epitomized by the existence and functioning of the executive, legislative and judicial arms of government is a major feature of democratic governance in the fourth republic. Similarly, intergovernmental relations and interactions existing among the arms of government, even though not as robust as one would have expected, but at least, it allows for some degree of debate and ventilation of ideas on issues of national importance. Besides, a great degree of independence exists among these arms of government; giving room for checks and balances on the measure of powers they exercise (Ibe, 2014).

The country has also experience some socio-economic and political gains since the return of democratic governance. Some of the successes are products of some of the governmental policies and programmes engendered by the democratic environment in place. Such gains include the introduction of new salary scale for civil servants, deregulation of the communication sector which led to the introduction of the Global System for Mobile telecommunication (GSM) and the debt relief secured for the country during the Olusegun Obasanjo administration. Moreover, the passage of the freedom of information bill, some measure of respect for the rule of law and the economic development vision inherent in the seven point agenda under late Umar Yardua represent some forms of democratic dividend. The establishment of nine federal universities and the commitment and drive towards the deregulation of the downstream sector of the petroleum industry 
by the administration of Goodluck Jonathan represent some of the gains of democratic governance (Igba, 2012). Also, at the state government level, states like Lagos, Kano, Rivers, Edo, Akwa Ibom and Jigawa are considered to have achieved, to some extent, some measure of infrastructural, human, and social development.

\section{Pains of Democratic Governance in the Nigerian Fourth Republic}

Democratic governance in the fourth republic to a large extent has failed to 'guarantee minimum conditions of governance, deliver democratic dividends, and development (Omodia and Aliu, 2013:39). The failure of democratic governance is evident in the persistent problems of food, employment, security, potable water, accessible health care, roads, qualitative education that plague most Nigerians. Moreover, the widespread manifestations of insecurity in the form of armed robbery, kidnapping, crude oil theft, militancy and insurgency partly explain the prevalent state of poverty in the country which democratic governance has failed to adequately tackle (Omodia and Aliu, 2013).

Elections have been characterized by violence since the inception of the Nigerian fourth republic. The 1999, 2003, 2007 elections were marred by ballot box snatching, political assassinations, bombings, killings, maiming of voters, arson, and abduction of electoral officials (Omotola, 2008, Omudiwe and Berwind-Dart, 2010; Aniekwe and Kushie, 2011). Specifically, Ogbonna Uche Ogbonnaya, the candidate of the opposition All Nigeria Peoples Party was assassinated on February 8, 2003 (Smah, 2008). Similarly, on July 2006, Funsho Williams, a People's Democratic Party governorship aspirant for Lagos state was assassinated (Omotola, 2008). More than 300 people were killed in the widespread violence that marred the 2007 state and national elections (Human Rights Watch, 2007). Equally, the 2011 presidential election was marred by an unprecedented post electoral violence, especially in the far North, resulting in the death of many innocent citizens (Human Rights Watch, 2011).

Political corruption has assumed an unprecedented dimension in the polity since the return to democratic governance in 1999. The weak and defective nature of institutions of accountability and transparency and prebendal character of political elite in the Nigerian fourth republic partly explains the widespread nature of corruption in the polity (Aliu, 2013). Given the revelation by the Economic and Financial Crimes Commission (EFCC) that billions of dollars of public funds have been stolen by politicians and government officials since the return of democratic governance, it safe to argue that corruption, to a large extent is official and institutionalized in Nigeria. For example, Lucky Igbinedion, an ex-governor of Edo State was convicted in 2008 for stealing more than $\$ 25$ million of 
public fund (Human Right Watch, 2011), while James Ibori, a former governor of Delta State was convicted in Britain in 2012 for defrauding the state of nearly $£ 50$ million (BBC, April, 2012). The impact of political corruption evident in the fourth republic on socio-economic and political development is devastating. Political corruption in its various forms have in part restrained economic development, increase poverty and unemployment; weaken public trust in government and democratic institutions and weakened accountability and the rule of law (Ogundiya, 2010).

The failure of democratic governance to meet the yearnings of most Nigerians in the fourth republic has degenerated into crisis of legitimacy. The problem of mutual distrusts among Nigerians is aggravated by the decline in public trust in the ability of government to provide security and improve their wellbeing. Some Nigerians willingly extend loyalty, obedience and allegiance to ethno-religious and communal groups for protection. The unhealthy rivalry among ethno-religious social groups has sometimes snowballed into violent conflicts in the country. The spates of ethnoreligious and communal conflicts that have ravaged Plateau, Kaduna, Kano and Nassarawa States since the return of democratic governance as well as the Niger Delta militancy and Boko Haram insurgency are good examples in this regard (Omodia and Aliu, 2013).

The masses have been at the receiving end of the poor performance of democratic governance in the fourth republic. With democratic governance, a system in which the elected officials and political leadership lives in opulence and affluence is entrenched, while majority of Nigerians live in poverty. Statistics indicates that over 70 percent of Nigerians live below the poverty line, while the World Bank ranked Nigeria among the poorest countries in the world with seven percent of the 1.2 billion extremely poor people (Daily Independent, 2014). The character of the Nigerian State and the ruling elites are core to the failure of democratic governance of the fourth republic to produce great dividends to the majority of Nigerians. The 'Nigerian state by virtue of its historical, socioeconomic and political conditions is fashioned to perpetuate elite exploitation of the socio-economic and political space and resources, protect foreign interests, promote ethnoregional and religious antagonism and undermine popular participation in the development and governance processes' (Aliu, 2014: 7). Moreover, most of the ruling elites of the fourth republic like most of their predecessors of the previous republics are 'corrupt, self-centered, incompetent, kleptocratic, ideologically and morally bankrupt, visionless, intolerant, autocratic, dishonest, naive, opportunistic, and parochial' (Aliu, 2014: 7). 


\section{Challenges to Democratic Governance in the Nigerian Fourth Republic}

The failure of the Independent Electoral Commission (INEC) to conduct free and fair election since the dawn of civil rule in 1999 represent a major setback to democratic governance in the Nigerian fourth republic. Some of the failings of INEC according to (Aderomu and Aliu, 2011) include the inability to provide a credible voter's registration exercise, failure to adequately enlighten the electorates on the electoral process, collusion of its officials with politicians to subvert the electoral process, insufficient electoral materials, ineptitude, and lack of capacity building. These problems of the Commission are linked to the issues of finance, autonomy, structure, logistic and security of job for officials. The implications for the polity are far reaching. One, the people votes do not count. Two, it makes people with dubious and questionable legitimacy rule over the people. Three, the situation may encourage the drive towards a one party state. Four, the sense of lack of impartiality on the part of the electoral body has generated an atmosphere of political instability (Aderomu and Aliu, 2011).

Economic development is essential to the survival of democratic governance. Lipset (1960. 31) succinctly capture this point in his argument that 'democracy is related to the state of economic development. The more well to do a nation, the greater the chances it will sustain democracy'. This implies that extreme poverty and income inequality is detrimental to sustaining democracy (Muller, 1995). Yet, economic wealth of a nation is not a precondition for democracy to thrive. Nevertheless, democracy has not been able to respond to the challenges of food, portable water, accessible health facilities, and good transport system in Africa (Moru, 2005:58). Evidently, the economic wellbeing of most Nigerians has continued to worsen since the return to democratic governance. The profligacy, corruption and waste of the political leadership have contributed to the problems of poverty, unemployment, and inadequate access to services. Over 70 percent of Nigerians continue to live below the poverty line, the supply of electricity is epileptic, infrastructure is bad, the rate of crime is on the increase, illiteracy and disease are prevalent and life is generally tough for the masses (Aderomu and Aliu, 2011; Aliu, 2014).

The massive level of corruption evident in the fourth republic is a major challenge to democratic governance. The prebendal nature and character of Nigerian politics is core to understanding the problem of corruption in the fourth republic. Generally, most politicians in Nigeria do not regard politics as a means to offer public service, but as a vehicle to capture state power, access and accumulate state resources for personal benefits. Evidently, 'the overwhelming allegations against and in some instances conviction of political leaders and legislators in the Nigerian fourth republic of bribery, nepotism, cronyism, award of phony contracts, inflation 
of contract sums, embezzlement, electoral fraud and abuse of office are indicative of the ruling elites consideration of politics as the means to capture state power and offices for economic benefits' (Aliu, 2013: 4).

The cost of financing the huge ministerial portfolios and special advisers appointed by the executive as well as servicing the huge numbers of Senators and Honorable members of the House of Representatives makes the democratic process in Nigeria to be an expensive venture. Presently, Nigeria spends about $70 \%$ of the national budget on the recurrent expenditure, which includes the cost of financing the large numbers of political appointees, with $30 \%$ of the budget going for capital expenditure. Besides, the legislature and judiciary are considered to be ineffective and in most cases do the bidding of the executive; which defeats the essence of checks and balances. The issues of god fatherism, electoral malpractices and the politicization of ethnicity and religion are also major obstacles to the democratic experience of the fourth republic (Okeshola and Igba, 2012).

\section{Conclusion}

The central thrust of the paper is an examination of the extent to which democratic governance in Nigeria's fourth republic has impacted on the state, economy and people from 1999 - 2014. The paper contends that while there are moderate gains that are connected to the democratic experience of the fourth republic, in reality the pains and woes that have befallen Nigerians since the return of democracy are overwhelming. The paper argues that the character of the Nigerian state, the nature of politics and importantly, the failure of the political leadership to provide purposeful and responsible leadership has undermined the capacity of the state to deliver public goods and services. The result is the decline in popular trust in the democratic processes and institutions. Moreover, the ruling elites are not sensitive to the aspirations of the public. They tend to dictate and direct the outcome of the public policy processes, and mobilize identity politics towards their selfish interests. This has constrained popular participation in governance; reinforces most citizens' sense of alienation and marginalization, and engendered more inequalities and social tensions. Therefore, the political leadership is key to ensuring that democratic governance enhances the standard of living of the people, and addressing "the fundamental problems of poor delivery of public goods and services, endemic poverty, corruption, inequalities, political intolerance, and blatant acts of impunity and lawlessness among the ruling elite' (Aliu, 2014: 5) which have become the striking features of democratic governance in the fourth republic. 
In line with the above, we therefore recommend that since the political leadership and ruling elites are critical to the capacity to deliver the dividends of democracy to majority of Nigerians, they will have to imbibe and practice the core values of good governance and democracy in government. The provision of a responsible, exemplary, purposeful and service oriented leadership will be crucial to reducing the problems of political corruption, politicization of ethnicity and religion, lawlessness and impunity as well as enhancing national security, delivery of public goods and services, and political stability. The quality of the political leadership is also critical to the strengthening of the democratic process and institutions (Omodia and Aliu, 2013).

There is the need for the citizens to become active participant in the governance process. The citizens must realize that they own the democratic process and as such they are strategically positioned to demand accountability, effective and efficient governance from the political leadership. Therefore, the politically active, effective, critical and well informed followership is fundamental to making democratic governance work as they 'can successfully challenge and contest the ownership of the democratic space with the elites. This can be in the area of agenda setting, electoral participation, de-emphasizing resort to ethnic, sectarian and religious politics and holding politicians to account for their stewardship' (Omodia and Aliu, 2013: 41). Moreover, to ensuring that democratic governance in the forth republic is development and people oriented, it is imperative that civil society organizations and social forces sustain their accountability, sensitization and mobilization roles.

\section{References:}

1. Abdullahi, A. A. and Saka, L. (2007). Ethno-Religious and Political Conflicts: Threats to Nigeria

2. Nascent Democracy, Journal of Sustainable Development in Africa, 9(3):21- 36.

3. Aderonmu, J and Aliu, M. (2011). The Dilemmas of Democratic Consolidation in Nigeria: The Experience of the Fourth Republic, Lapai International Journal of Management and Social Sciences (LIJOMASS), 4(1): 91- 107.

4. Adejumobi, S. (2004) Democracy, Good Governance and Constitutionalism in Africa, In S. Odion-Akin (ed). Governance: Nigeria and the World, $(11$ - 22) Lagos: Centre for Constitutionalism and Demilitarisation.

5. Alabi, Mojeed. Olujinmi. A. and Fashagba, Joseph. Yinka. (2010). The Legislature and Anti-corruption Crusade under the Fourth Republic of Nigeria: Constitutional Imperatives and Practical 
Realities, International Journal of Politics and Good Governance, 1(1.2) Quarter II: 1 - 39.

6. Aliu, M. (2013). Legislative Corruption and Democratic Consolidation in the Nigerian Fourth Republic, Journal of Sustainable Development in Africa, 15(6): 101 - 112.

7. Aliu, M. (2014).The State, Development and Governance in Africa: The Nigerian Experience, IOSR Journal of Humanities and Social Sciences (IOSR-JHSS) 19(4) Ver. I (Apr. 2014): 21-32

8. Aniekwe, C. C. and Kushie, F. 2011. Electoral Violence Situational Analysis: Identifying Hot Spots in the 2011 General Elections in Nigeria, National Association for Peaceful Elections in Nigeria (NAPEN) and IFES, Pp $1-47$.

9. BBC. 2012. Former Nigeria governor James Ibori jailed for 13 years (Online), Available from: www.bbc.co.uk/news/worldafrica17739388, 17 April, 2012.

10. Daily Independent. (2014). Democracy Day: What Benefits for Nigerians? (Online), Retrieved From: http://dailyindependentnig.com/2014/05/democracy-day-benefitsnigerians/ on October 28, 2014.

11. Egwemi, V. and Aliu.M. (2010) Leadership, Corruption and the Crisis of Development in Nigeria. KOGJOURN, 1 (1): $146-168$.

12. Higley, J. (2008). Elite theory in political sociology, University of Texas at Austin.

13. Human Rights Watch. 2007. Criminal Politics: Violence, 'Godfathers' and Corruption in Nigeria, New York, HRW Report, Volume 19, No.16 A, October 9, Pp 1-121.

14. Human Rights Watch. 2011. Corruption on Trial? The Record of Nigeria's Economic and Financial Crimes Commission, New York, USA: Human Rights Watch, August, Pp 1-64.

15. Human Rights Watch (2011) Nigeria: Post-Election Violence Killed 800 - Promptly Prosecute Offenders, Address Underlying Causes, May 16, 2011 https://www.hrw.org/news/ 2011/05/16/nigeria-postelection-violence-killed-800

16. Ibe, U. (2014). Gains from Democratic Governance, (Online), Retrieved

From:

http://nigerianobservernews.com/06052014/features/features2.html\#. VABZK6KOCIg on October 28, 2014.

17. Igba, A. ( 2012), An Assessment of Dividends of Democracy in Nigeria: A Study of Buruku Local Government Area of Benue State (1999 - 2011). A B.Sc Project Submitted to Department of Sociology, Ahmadu Bello University, Zaria, Nigeria. 
18. Lipset, S. M. 1960. Political Man: The Social Bases of Politics, Garden City New York: Doubleday.

19. Moru, J. (2005). The Challenges of Democracy in Nation Building: Africa in the 21st century, In G. Onu and A. Momoh (eds) Elections and Democratic Consolidation in Nigeria, (55 - 68) Lagos: Triad Associates.

20. Muller, E, N. (1995). Economic determinants of democracy, American Sociological Review, 60:

21. $966-982$.

22. Olaitan, W.A. (2005). Elections: The Making and Unmaking of Democracy, in G. Onu and A. Momoh (eds) Elections and Democratic Consolidation in Nigeria, (43 - 54) Lagos: Triad Associates.

23. Ogundiya, I. S. 2009. 'Political Corruption in Nigeria: Theoretical Perspectives and Some Explanations', Anthropologist, 11(4): 281 292.

24. Ogundiya, I. S. 2010. 'Corruption: The Bane of Democratic Stability in Nigeria', Current Journal of Social Sciences, 2(4): 233 - 241.

25. Okeshola, F. B and Igba, A. (2013). An Assessment of Dividends of Democracy in Buruku Local. Government Area of Benue State Nigeria (1999 - 2011). (Online), Retrieved From: https://www.google.com.ng/?gws_rd=ssl\#q=AN+ASSESSMENT+OF $+D I V I D E N D S+O F+D E M O C R A C Y+I N+B U R U K U+L O C A L+G O V$ ERNMENT+AREA+OF+BENUE+STATE+NIGERIA++\%281999+ $\% E 2 \% 80 \% 93+2011 \% 29+$ on October 28, 2014.

26. Okoh, A. O. (2010). Religious Cleavages, Inequalities and Unitarism vs Federalism in Nigeria. In R.F. Ola and J.E. Imhanalahimi (Eds) Nigerian Political System: Trends and Perspectives (pp. 166-191). Benin City: University of Benin.

27. Omodia, S. M. (2011). Political Elites and the Challenge of Free and Fair Elections in the Nigerian Fourth Republic, Canadian Social Science, Vol. 7, No. 5, 2011, pp. 111-115

28. Omodia, S.M. and Aliu, M. (2013). Governance and Threats to National Security in Emerging Democracies: A Focus on the Nigerian Fourth Republic, Research on Humanities and Social Sciences, 3(4): $36-42$.

29. Omotola, S. (2008). Explaining Electoral Violence in Africa's 'New' Democracies, Revised Version of a Paper on Electoral Reform, Political Succession and Democratisation in Africa, Presented at the 27th Annual Conference of the Nigerian Political Science Association (NPSA), Held at Benue State University, Makurdi, Benue State, Nigeria, 16-19 November 2008. 
30. Onwudiwe, E. and Berwind-Dart, C. (2010). Breaking cycle of electoral violence in Nigeria, United States Institute of Peace, Special Report 263, December.

31. Seteolu, D. 2004. 'The Challenges of Leadership and Governance in Nigeria', in S. Odion-Akin (ed.) Governance: Nigeria and the World, [48]. Lagos: Centre for Constitutionalism and Demilitarization, Pp 70 $-78$.

32. Smah, O. S. (2008) 'Money Politics and Electoral Violence in Nigeria', in V. A. O Adetula (ed) Money and Politics in Nigeria, International Foundation for Electoral System (IFES), Nigeria. Pp 65 -84 . 